of communicating to the Royal Society of London six years ago.

2. I am also very glad that Prof. Langley has proved by his most refined and crucial observations on the direct radiating powers of spot, penumbra and photosphere surface, combined with the continuous register of the amount each day of the spotted portion of the sun, that sun-spots have no sensible power in themselves for producing any notable change on terrestrial climate; because, $\mathrm{Sir}$, in that paper of six years ago, and still in the hands of the Royal Society, I deduced that sun-spots were consequences, rather than causes, of the great periodical waves of heat which come upon the earth from without; and I proved that conclusion three times over, or for three successive cycles of the eleven-year sun-spot period.

3. As we are now on the commencement of another of those cycles, I must regret that the chief speakers seemed to intimate that almost all their idea of further investigation into the origin of those mysterious heat-waves received by the earth from without and apparently from the sun, centred in causing to be made more sun-spot observations; for, Sir, not only did it sound very much like proposing to lock the stable-door as soon as it should be announced that the horse is no longer therein, but there are further features accompanying those occasional great heat-waves, showing that they must originate in something much more intense, viclent, and complicated than those comparatively harmless little phenomena, the dark spots. PIAzzi SMYTH,

Edinburgh, December 5 Astronomer Royal for Scotland

\section{Radiant Points of Shooting Stars}

13ETween October 13 and November 28, watching for fortynine hours, I observed 367 shooting stars, 306 of which were well seen and their paths registered. On going carefully over them some thirty-five radiant points are shown, about twenty-five of which are good positions, while the remainder are open to more or less doubt. The following are the twelve principal ones:-

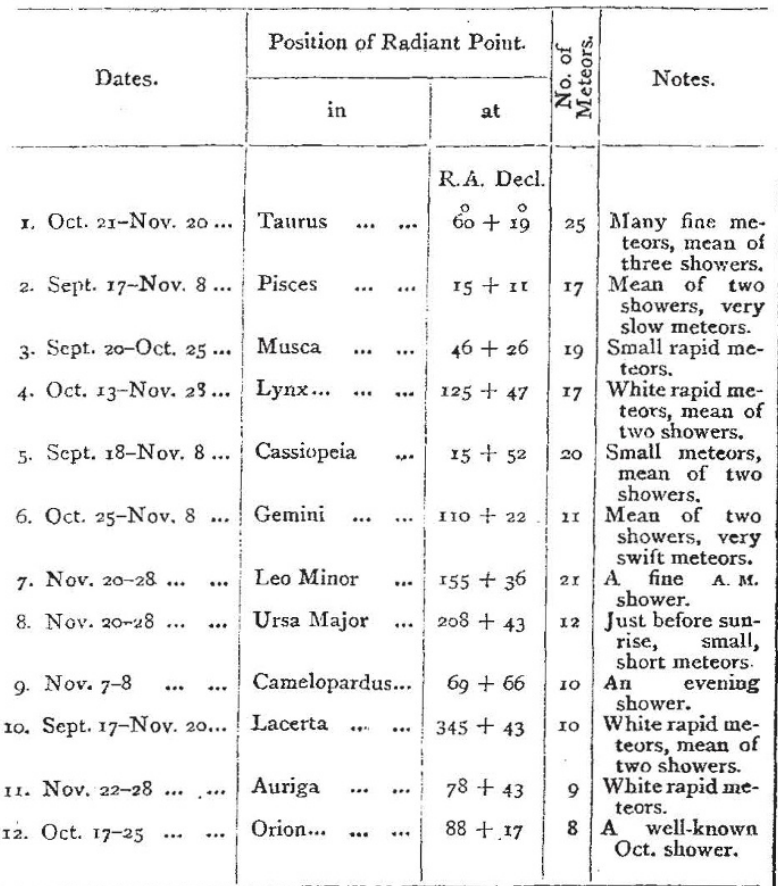

Several of these positions are the mean of two showers, one seen in October the other in November, and evidently identical. No. 7 in the list is possibly new, and was a very active shower from near Leo; the meteors were rapid and white, leaving phosphorescent streaks. No. 8 is quite new, and three other radiants found on the mornings between November 19 and 28 are new. They are :-

$$
\text { Position. }
$$

R.A. Decl.

I. Near $\tau$ Leonis ... $170+4 \ldots 6$ meteors, very swift.

2. In Sextans... ... 153 S 1 ...6 6 meteors.

3. a Boütis ... ... $212+18 \ldots 7$ meteors,
The positions given are in most cases very accurate, and each of them represents a well-marked shower. The new radiants are visible preceding sunrise, and this may account for their having previously escaped detection.

Generally the meteors of Octuber-November were very small. The magnitudes of the 306 registered were :-

$x$ or $=$ 2nd mag. 3 rd mag. $\quad$ 4th mag. 5th mag. 6th mag. Total.
xst mag.

$\begin{array}{lllllllllll}19 & \ldots & 49 & \ldots & 6 \mathbf{r} & \ldots & 107 & \ldots & 65 & \ldots & 5\end{array}=306$.

I have lately found meteors very much more frequent after midnight than before it. In November, I $3 \frac{3}{4}$ hours watching, P. M., gave 79 , while 12 hours watching, A. M., gave 133 . Thus 1 have noted about double the number in the mornings than in the evenings. I found a similar difference in October, though have made no special comparisons to find if it has also been shown in the other months of the year. I usually find meteors show a progressive increase in numbers as the night advances, being at a minimum early in the evening hours and at a maximum just before the morning twilight.

Ashleydown, Bristol

William F. Denning

The Atlantic Ridge and Distribution of Fossil Plants

Ir has occurred to me that the discovery of the narrow belt of suboceanic highlands extending in a sinuous course down the length of the Atlantic, as shown in the Challenger chart, removes a difficulty that has been present to students of fossil botany. When the area was land these hills would probably form a ridge sufficiently high to have a temperature cool enough to explain the migration across the tropics of plants living in a temperate or even cooler climate.

M.

\section{Antedon Rosaceus (Comatula Rosacea)}

THE letters of your correspondents with reference to the above, seem to me to fail to prove that there is any public recorded instance of its capture in the stalked (brachial) form at Torquay before the instance noted by the Birmingham Natural History and Microscopical Society in 1873 . Of course if Prof. Aliman took a specimen in the pre-brachial stage there in 1863 , and $\mathrm{Mr}$. Gosse the adult animal in 1864 , the stalked form (brachial) must have been there as well, but was probably overlooked.

As to the change of name to which Mr. 'Thomas R. R. Stebbing objects, I certainly thinis that Dr. Carpenter, in his monograpi before referred to, has deduced ample reasons for the substitution of Antedon for Conatula, "on the grounds of priority, in accordance with the rules of zoological nomenclature, and in concurrence with the views of Dr. J. E. Gray, Sir Wyville Thomson, and the Rev. A. Merle Norman." Birmingham, December Io

W. R. Hughes

\section{"Towering" of Birds}

My experience goes to show that the towering action, although most frequent in the gallinaceous birds, is by no means confined to them. In the first case which came under my notice the bird was the common godwit. It was feeding on the border of a marsh, and I being very young at the time, committed the unsportsmanlike act of firing at it on the ground. Immediately on being hit the bird rose perpendicularly to a height of about 30 feet, then turned over on its back and fell dead almost on the spot from which it started.

Since then I have seen the same movement in the dunlin and some other species of Tringa, in the sanderling, the whimbrel, and, if I recollect rightly, in the lapwing plover, but in no other birds, excepting of course those mentioned by Mr. Romanes.

I bave never seen a towering shore bird, after being struck, fly any considerable distance before towering, and those which have towered directly on being hit have always received a slight wound at the base of the brain, but there is little doubt that pulmonary hæmorrhage is the principal cause of this curious action.

December 12

F. W. Millett

\section{THE SPECTRUM OF THE NEW STAR 1}

NOTWITHSTANDING the bad weather and the feeble light (4th to $5^{\text {ti }}$ mag.), I have been able to investigate pretty completely the spectrum of the light

$x$ Sur le spectre de Y'etoile nouyelle de la constellation du Cygne. Note by M. A. Cornu, read at the Paris Academy of Sciences, December ru. 